\title{
Correction to: Intracellular inflammatory signalling cascades in human monocytic cells on challenge with phytohemagglutinin and 2,4,6-trinitrophenol
}

\author{
N. Prajitha ${ }^{1}$ - P. V. Mohanan ${ }^{1}$ (D)
}

Published online: 9 December 2021

๑) Springer Science+Business Media, LLC, part of Springer Nature 2021

Correction to: Molecular and Cellular Biochemistry https://doi.org/10.1007/s11010-021-04296-x

In the original publication of the article, Fig. 1B was published incorrectly. The correct version of Fig. 1 is provided in this correction.

P. V. Mohanan mohanpv10@gmail.com

1 Toxicology Division, Biomedical Technology Wing, Sree Chitra Tirunal Institute for Medical Sciences and Technology (Govt. of India), Poojapura, Trivandrum, Kerala 695012, India 


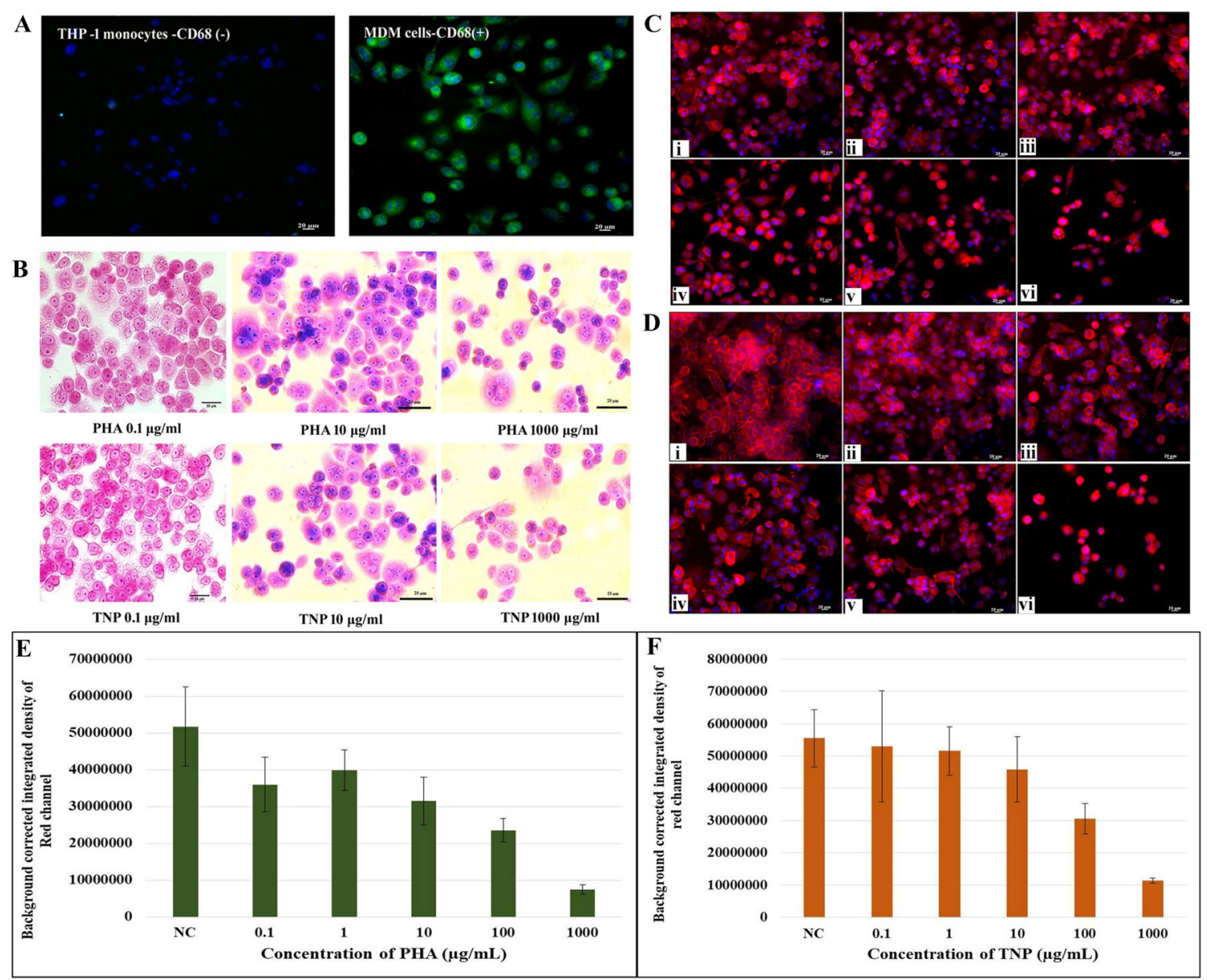

Fig. 1 A Expression of CD68 on MDM cells after differentiation of THP-1 cells using PMA. B Giemsa staining for analysis of cellular morphology following $24 \mathrm{~h}$ exposure with PHA and TNP $(0.1 \mu \mathrm{g} /$ $\mathrm{ml}, 10 \mu \mathrm{g} / \mathrm{ml}, 1000 \mu \mathrm{g} / \mathrm{ml})$. Scale bar $20 \mu \mathrm{m}$, Magnification 40x. C Rhodamine phalloidine staining of MDM cells (i) Control (ii) PHA $0.1 \mu \mathrm{g} / \mathrm{ml}$ (iii) PHA $1 \mu \mathrm{g} / \mathrm{ml}$ (iv) PHA $10 \mu \mathrm{g} / \mathrm{ml}$ (v) PHA $100 \mu \mathrm{g} /$ ml (vi) PHA $1000 \mu \mathrm{g} / \mathrm{ml}$. D (i) Control (ii) TNP $0.1 \mu \mathrm{g} / \mathrm{ml}$ (iii) TNP $1 \mu \mathrm{g} / \mathrm{ml}$ (iv) TNP $10 \mu \mathrm{g} / \mathrm{ml}$ (v) TNP $100 \mu \mathrm{g} / \mathrm{ml}$ (vi) TNP $1000 \mu \mathrm{g} / \mathrm{ml}$ for 24 h. Quantitative representation of Rhodamine phalloidine for $\mathbf{E}$ PHA and F TNP. Untreated cells were used as control. The scale bar represents $20 \mu \mathrm{m}$. Magnification 20x

Publisher's Note Springer Nature remains neutral with regard to jurisdictional claims in published maps and institutional affiliations. 